\title{
Character Education in Early Childhood Based on Family
}

\author{
Uswatun Hasanah, Much Deiniatur \\ Faculty of Islamic Education and Teacher Training, IAIN Metro Lampung
}

\begin{abstract}
Family is a place of learning that is full of true love and affection. Good characters embodied in the family are very fundamental human characteristics. Children's capability to function as responsible citizens must be nurtured early on. Family is the smallest social unit that has an important role in the development of children's character, which lies in character education model given by the parents to their children. Character education within a family has not been conceptualized in a way that leads to a variety of educational praxis according to the understanding of each parent. The purpose of the study is to describe what values can be internalized to a family since early childhood. The research method used is literature study (library research), which is a research conducted by the researchers by collecting a number of books, magazines, leaflets pertaining to problems and research objectives. The findings show that children's character education should start from within the family, because family is the smallest unit of society and it will depend on parents to teach children from early age. Children's character building within the family is not an easy practice because it requires systemic handling. There are interrelationships of other components, such as schools and community environments, which is necessary in its implementation. Character education in early childhood should start from the family through the eight family functions including (1) Education Function, (2) Protection Function, (3) Affection function, (4) Socialization function, (5) Reproduction Function, (6) Religious Functions, (7) Economic Functions, and (8) Recreation Functions.
\end{abstract}

\section{KEY WORDS}

Character education, early childhood, family

CORRESPONDING AUTHOR:

email: uswatun.hasanah@metrouniv.ac.id.

Manuscript submitted June 28, 2018; accepted Agustus 18,

2018.
Copyright: @2018 This is an open access article under the terms of the Creative Commons Attribution License, which permits unrestricted use, distribution, and reproduction in any medium, provided the original author and source are credited

\section{INTRODUCTION}

Education is all life situations influencing an individual's growth as learning experience occurs in various environment and throughout life. Furthermore, education is the most appropriate medium in developing children's potential and build their character both in terms of skills and knowledge. Therefore, education is constantly built and developed so that its implementation will engender the expected generation (Hasanah, 2016, p. 73). Abdul Munir Mulkhan (1993, p. 64) thought that education is a humanitarian effort conducted consciously and rationally, and to achieve the never-ending humanitarian goals cannot be realized only in one generation. 
In the Law of National Education System No. 20 of 2003 (2003, pp. 5-6), it is mentioned that education is a conscious and planned effort to realize learning atmosphere and learning process so that students actively develop their potential to acquire religious spiritual strength, self-control, personality, intelligence, noble character, and the skills needed by themselves, society, nation, and country. Moreover, education in a family and its surrounding environment is included in informal education. Mantep Miharso (2004, p.13) explains that family is the basic kinship unit in a society, which consists of mother, father, and children, or the family members who becomes the dependents. Nuclear family or the main family consists of husband, wife, and children.

Character is a collection of values heading towards a system that underlies thinking, feeling, attitude, and behavior performed by someone. In order to build good characters, one could achieve it through education and constant training, which could start from the family. Since people's characteristics are influenced by its environment, the engraining of religious, moral, and manner values is important to be done from early age.

Children are young humans who have potential that still needs to be developed. Children have specific characteristics that are unique and unlike those of adults; they are active, dynamic, excited, and curious of things they want to see, listen, feel, and as if they have never explored and learned. Children are egocentric, have natural curiosity, sociable, unique, filled with fantasy, have shortspanned attention, and are in the most potential period for learning. Children's education can be carried out in formal, nonformal, and informal approach. Formal education (government organized education) of children can be acquired through preschool, kindergarten, elementary school, senior high school, and higher education. Non-formal education (institution organized education) could be acquired through PAUD, TPA, KB, or the like, and to higher education. Lastly, informal education is acquired since they are in their mothers' womb (prenatal education) and from their environment (Mursid, 2015, p. 34).

Children at early age is considered within a critical and sensitive period because it will determine their attitudes, values, and behavioral patterns in the future. During this critical period, their potential, tendency, and sensitivity will be actualized when they receive the proper stimulus. According Reber in Rahmat Rosyadi (2013, p. 21), during critical and sensitive period, children need to receive stimulus, proper treatment in order to have positive impact. On the other hand, if this period is overlooked, external influence will not have any effect on children character formation. The critical growth period during childhood is strongly related to biological development especially child's brain growth, because brain contains of nerve structures functioning to control physical and mental activities as they grow. During this childhood, child's brain is not optimally developed, in which proper stimulus during this critical period will have optimum brain development.

According to M. Fauzi Rachman (2011, p. $59)$, between 0 to 5 years old is the golden 
period for child's brain. Children's brain will develop rapidly and easily accept external stimuli during this age. This period is called children's golden age. Then, what should we do during this age? Parents need to give them stimuli and learn while playing, give them nutritious foods according to their biological needs. Various studies show that more than $50 \%$ of individual growth occurs during childhood, which is also considered as productive period for brain growth. During this age, nutrition intake will have amazing influence. Furthermore, moral values should also be introduced during this period.

Children education during early age basically include all efforts and treatment performed by teachers and parents during the process of care, nurture, and education for children by creating atmosphere and environment, in which children could explore various experiences that will give them the opportunities to learn and understand learning experiences they acquire through environment by observing, mimicking, and directly experimenting that happen constantly and involve children's potential and intelligence (Sujiono, 2009, p. 7).

The hardest challenge in educating children is to eschew them from "hubbu ad-dunya wa karaahiyat al-maut" (love for world and scared for death) disease. Family has important role in education and family is place for children's first growth and development. Children are influenced by the family members during the most important growth period of children's education, which is the first years of their life (preschool age). During this period, what they learn will stick with them, and it will not easily go away or change in the future. Family is the main and the first educational institution for children. The education they receive from the family serves as the base for their subsequent education at school. Parents serve as the main educator for children and are solely in charge of their children's education.

\section{RESEARCH METHOD}

By looking at the implicit meaning of the paper title and problem studied in this article, this research is considered as literature research by employing qualitative approach, which means research that does not conduct quantitative data calculation (Moleong, 1990, p. 2)

There are several main keys in literature (archival) research by using qualitative approach; they are: (a) the researcher is the main instrument that will read the literature accurately; (b) the research is done descriptively. It means describing in the form of words and picture not in the form of number; (c) more emphasized on the process not on the result because the literature is a work that rich of interpretation; (d) the analysis is inductive; (e) the meaning is the main point.

The main or primary literatures for this research are books on psychological education and family education. As a literature research, the method of data collection used in this research is documentation method, which focuses on data about variables in the form of books, notes, transcripts, newspaper, magazines, 
journals, and so on. Data analysis technique used is descriptive analysis.

\section{RESULTS AND DISCUSSION}

\section{Definition of Character Building}

According to Abdul Majid and Dian Andayani in their book entitled Pendidikan Karakter Perspektif Islam (2012, p. 11), etymologically, the word character comes from Latin word kharakter or kharassein in Greek, which means to mark, or in French carakter, which means to sharpen or to deepen. Furthermore, character in English according to John M. Echols and Hasan Shadily in Kamus Inggris-Indonesia (2003, pp. 109-110) means watak (trait), karakter (character), sifat (personality), peran (role), and huruf (letter).

Terminologically, experts define character differently. Doni Koesoema (2010, p. 80) states that in understanding character is similar to personality, which could also mean characteristic, or style, or one's distinctive character, which comes from developments they receive from their environment, for example family during childhood.

According to E. Mulyasa (2012, pp. 3-4), character is someone's attitude in responding to a certain situation that they realize through their behavior. Character could also be defined as a totality of inherent personal characteristics and can be identified in unique individual behavior, in the sense that these characteristics distinguish one individual and another. Since these character traits can be identified in individual behavior and are unique, the character is very close to the individual's personality. Furthermore,
Amirulloh Syarbini (2016, p. 30) believes that character is a steady, stable, and special nature that is inherent in a person that makes him behave and act automatically, cannot be influenced by circumstances, and without needing thought or consideration. Understanding these characters is defined as an act that has been integrated in a person's soul / self, or human spontaneity in behaving so that when it appears there is no need to think about it.

The definition of Character in particular include values that are typically good (knowing the value of goodness, willing to do good, lead good life in reality, and have a good impact on the environment) which are embedded in and manifested in behavior. Characters coherently emanate from the results of thought, through the heart, exercise, and the feeling and intention of a person or a group of people. Character is a characteristic of a person or group of people that contains values, abilities, moral capacity, and determination in facing difficulties and challenges. In relation to education, character building can be interpreted as value education, character education, moral education, and personality education, which aims to develop the students' ability to have good or bad decisions, maintain goodness, realize and spread goodness in daily life whole-heartedly (Salahudin and Alkrienciehie, 2013, p. 42).

Ki Hadjar Dewantara in Ihsana El-khuluqo (2015, pp. 54-55) explained that the concept of character education is considered very necessary and even must be given to children so that they will later become human beings 
who have personality and are committed. Therefore, he described this character education with four steps that need to be taken from Islamic teachings, namely: Shari'at, Hakikat, Tarikat and Ma'rifat.

First, at Syari'at level, it is suitable to be given to young children (kindergarten level). The method used is setting habits to behaving or doing well according to the rules or general norms in the community. Children do not have to be given a theory of character, but are immediately accustomed to good character such as greeting when meeting friends, expressing respect when meeting parents, and so forth.

Early Childhood Education has a very strategic role in determining the history of child development because it is the foundation for children's personality. Children who get the proper and effective guidance from early age will be able to improve physical and mental health, which has impact on improving children's learning achievement, work ethic, and productivity so that they are able to be independent and optimize their potential (Deiniatur, 2017, p. 192).

Secondly, the level of Hakikat is given to elementary school children. On this period, children are accustomed to doing and behaving according to general regulations or measures. However, at the same time, they are given simple understandings about the reason they should follow the rules. For example, besides being accustomed to greeting when meeting friends, they were also given an understanding of the importance of saying that greeting, for example, greetings can lead to bonding and intimacy between friends.

Third, the Tarikat Level is given to children of junior high school age. During this period, children were still accustomed to behaving and doing well according to general provisions. Furthermore, they were also given understanding of the importance of doing so. However, at the same time the education is also accompanied with suitable supporting activities. For example, doing arts, poetry, and exercise. One instance is how junior high school children are trained to dance "slowly" while explaining the meanings of the movements in them to instill the concept of character.

The last level is Ma'rifat Level. It is suitable for high school and/or vocational school students. In this period, children are given understanding and awareness so that if they apply the knowledge and behave properly, it is not merely part of their habits and understanding. Rather, it is because they understand from their heart and have the awareness to do such things.

In character building, parents must harmonize three humans' potentials, namely:

1.) Cognitive (knowledge); 2.) Affective (attitude); and 3.) Psychomotor (skill).

Thus, the definition of character education is the personality or character of permanent human natures, which becomes a special sign that distinguishes one person from another.

\section{Concept of Family}

Etymologically, family is people living in a house, which at least consists of husband, wife and children. In the Law No. 23 of 2002 concerning child protection (p. 3), it is stated 
that family is the smallest unit in the community which consists of husband and wife or husband and wife, or mother and child, or father and child, or a family with direct bloodline, and until the third generation.

In sociology, it was firstly coined by Auguste Comte. Even though Ibn Khaldun was considered the father of sociology, Sociology Perspective suggests that family is the smallest social group characterized by a place where they live together, with economic and reproductive cooperation. In sociology, family has a definition, which is batih. Batih becomes the main community joint. Batih is a place of birth, a place of education, and a place for children's character development. Batih could also serve as a symbol, a place and purpose of life with the wife. In English, keluarga is known as family, while in French it is called famille. These terms refer more to families in a very broad context, which means people who know each other. The meaning of family in both languages is considered too broad, because it refers to all groups whose members know each other. However, in Arabic terminology, the term family is equated with the word usrah, which in its origin means a bond or makes it a prisoner. It was derived from the word al-asru that means to tie with a rope, then it extends to all bonds that are bound, either by rope or by other media (Jamaluddin, 2013, pp. 116-117).

Abdullah Gymnastiar in Amirrulloh Syarbini (2016, p. 73) stated that family is a small organization in which there is a leader and some are led. A father is the head of the family who serves as the captain in the household. He is the one who directs and controls where he will bring his family.

Among the obligations imposed by Allah on someone's shoulders is the obligation of educating children or descendants, also trying to save themselves, the wives and children from the punishment of hell fire. As Allah commands in Qur'an:

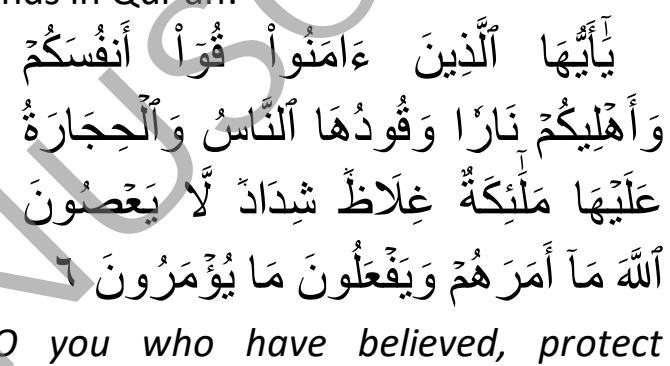
yourselves and your families from a Fire whose fuel is people and stones, over which are [appointed] angels, harsh and severe; they do not disobey Allah in what He commands them but do what they are commanded" (Q.S. At-Tahrim, p. 6).

\section{The Roles and Functions of Family}

Family has a very important role in the effort to develop the child's personality. The care of parents who are affectionate and educated about the values of life, both religious and socio-cultural, is a conducive factor to prepare children to be healthy individuals. Family is also seen as an institution that can meet human (human) needs, especially the need for the development of the child's personality and the development of human race. If we associate the role of family with the needs, as stated by Abraham Maslow, then family is the first institution that can meet these needs, both physical biological and sociopsychological needs. 


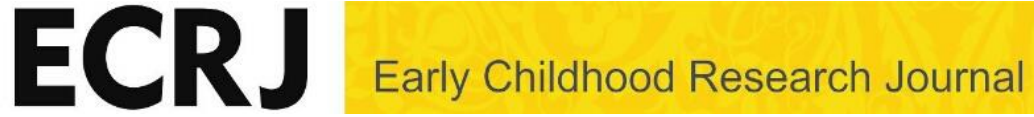

Moehammad Isa Soelaeman in Amirulloh Syarbini $(2016$, p. 75$)$ suggested that family should act as a protector and educator of the family members, as the liaison with the community, as the fulfilment of their economic needs, as a guide to their religious life, as the organizer of family recreation, and the creator of a safe and comfortable atmosphere for all family members.

The values for children's character education could be realized through eight functions of family. They include:

a. Educational Function

The educational function of a family relates to children's education in particular and the education of family members in general.

Education is the process of changing the attitude and behavior of a person or group of people to mature humans through teaching and training. Since early on, humans have needed education in the process of development into adulthood. Child development at their early age is very important and will determine its quality in the future (Uswatun Hasanah, 2016, p. 717).

Basically, the implementation of education function is the realization of one of the responsibilities borne by parents towards their children. According to Ahmad Tafsir in Amirulloh Syarbini (2016, p. 76), parents are first and foremost educators for children. Parents are called first educators for children because children get education for the first time through them. Parents are referred to as primary educators due to the magnitude of influence that occurs caused by their education in the formation of children's character.

b. Protection Function

Protection function means that the family could become a refuge that provides a sense of security, peace of mind and inner life since children are in their mother's womb until they become adults and elderly. The substance of family is to protect its members from things that endanger them, both in the world and in the hereafter.

\section{c. Affection Function}

The main characteristic of a family is strong emotional bond between its members (i.e., husband, wife and children). In family, a sense of compassion is formed, a sense of togetherness and a sense of intimacy animate its members. This is where the family's affection function is needed; it becomes the driving force and the motivator of compassion and love among its members.

\section{d. Socialization Function}

The socialization function of family closely relates to the task of bringing children into a more real and broad social life. Since after all, children must be brought to a life of friendship, interacting with family, neighbors, and becoming a community member in their neighborhood.

In order to carry out the socialization function, family has the position of connecting children in social life and social norms. In addition, the factors that support the importance of family's role in the process of child socialization are as follows: 
1) Family is a small group whose members interact face to face in a closed manner; 2 ) Parents have strong motivation to educate children, because they are the labor of their affection; and 3) Because social relationships in the family are permanent.

Socialization function shows the family role in shaping the child's personality. Through social interaction in the family, children learn patterns of attitudes, behavior, beliefs, ideals, and values in the community within the context of their personality development (Mursid, 2015, p. 72).

\section{e. Reproduction Function}

Family as an organism has a reproductive function, in which each married couple who are bound by a legal marriage can give quality offspring so that they can give birth to children who will inherit and become the successor for the task of humanity.

\section{f. Religious Function}

Family has religious function, which means that family is obliged to introduce and invite their children and other family members towards religious life. The purpose is not merely to know religious rules, but to be a religious being as an individual who is aware of his position as a creature created and endowed with endless favors, in which it will stimulate him to fill and direct his life to serve Allah, towards His blessings.

\section{g. Economic Function}

The economic function aims to improve the standard of living of every family, which is reflected in the fulfillment of basic needs such as eating, drinking, health, and so on, that becomes the basic prerequisites in fulfilling the needs of a family's life in an economic perspective.

h. Recreation Function

Recreation function of a family is a function related to the role of the family in creating comfortable, pleasant, warm and passionate environment for each family member to relieve their fatigue. Family, which is filled with friendly, sincere, and warm atmosphere among its members, will generate strong relationship between family members who are trusting, free of burden and colored by relaxed atmosphere.

Children are under the supervision of their father and mother when they are young. If they have grown up or matured, they live independently, wading through their own life with other community members. In other words, children who live under their parents' supervision are just waiting for their adulthood. Therefore, fathers and mothers need to provide the perfect attention to their children from within the womb until they can be released to the community to live an independent life (Rachman, 2011, p. 3).

\section{Basic Development of Character Education}

Conceptually, the basis for the development of character education rests on the cognitive, moral and social development of children as learners since these factors have major influence on the formation and development of children's character. We will 
explain the three developments in the following section. They are:

\section{a. Cognitive Development}

The term "cognitive" comes from the word "cognition" whose equivalent is "knowing." In a broad sense, cognition (cognitive) is the acquisition, arrangement, and use of knowledge. In its subsequent developments, the term cognitive becomes popular as one of the domains or areas of human psychology which includes every mental behavior related to understanding, consideration, processing information, problem solving, intentionality, and belief. This psychology and center of mind is also related to konasi (volition) and affection (feeling) which are related to the realm of taste (Shah, 2010, p. 65).

The other word for cognitive development is the development of brain for reasoning capacity or intelligence. Intelligence development occurs very rapidly until adolescence. After that, it tends to stagnate or gradually decline. The peak of humans' cognitive development is generally achieved at the end of late adolescence (Danim and Khairil, 2011, p. 77)

Piaget explained that there are several cognitive development phases on human; they are:

Table 1.1.

Stages of Human's Cognitive Development

\begin{tabular}{|l|l|l|}
\hline Age & Period & \multicolumn{1}{c|}{ Characteristics } \\
\hline $0-2$ & Sensory-motoric & $\begin{array}{l}\text { Babies learn to distinguish } \\
\text { between themselves and } \\
\text { other objects in their } \\
\text { environment, learn the } \\
\text { difference between "me" } \\
\text { and "not me" }\end{array}$ \\
\hline $2-4$ & Pre-operational & Children are still very \\
\hline
\end{tabular}

\begin{tabular}{|c|l|l|}
\hline & thinking & $\begin{array}{l}\text { egocentric, but now classify } \\
\text { objects in a simple way, } \\
\text { especially with important } \\
\text { individual features. }\end{array}$ \\
\hline $4-7$ & Intuitive & $\begin{array}{l}\text { The child classifies things } \\
\text { that are more general, but } \\
\text { does not realize that he is } \\
\text { using the lower class }\end{array}$ \\
\hline $7-11$ & $\begin{array}{l}\text { Concrete } \\
\text { operation }\end{array}$ & $\begin{array}{l}\text { Children can use logical } \\
\text { operations, such as } \\
\text { reversal, deliberate } \\
\text { classification, and } \\
\text { serialization. }\end{array}$ \\
\hline $11-15$ & Formal operation & $\begin{array}{l}\text { Children become more } \\
\text { conceptual and able to } \\
\text { think in abstract ideas }\end{array}$ \\
\hline
\end{tabular}

Source: Sudarwan Danim and Khairil, Psikologi Pendidikan (dalam perspektif baru). (Bandung: CV. Alfabeta, 2011), p. 79

b. Moral development

According to Amirulloh Syarbini (2016, pp. 57-58), the moral term is derived from the Latin word "Moris" which means customs, habits, rules or values, or ways of life. Whereas, morality is a willingness to accept and carry out rules, values or moral principles. Moral development of a child is strongly influenced by his environment, especially from his parents. He learns to recognize values and behaves according to these values. In developing children's morals, the role of parents is very important, especially when children are still young. The process of moral development of children can take place through several ways, including: (1) Direct education, which is through the cultivation of understanding of wrong behavior properly, or right or wrong by parents, teachers or other adults; (2) Identification, which is done by identifying or imitating the appearance or moral behavior of someone who becomes his role model (e.g., parents, teachers, Muslim scholars, 
or other adults); (3) trial and error process, which is organized by developing moral behavior experimentally. Behavior that gets praise or appreciation will continue to be developed, while the behavior that brings punishment or reproach will be stopped.

\section{c. Social Development}

Social development is the achievement of maturity in social relations. It can also be interpreted as a learning process to adjust to group norms, morals, and traditions; merge oneself into a unity; and ability to communicate with each other and work together.

Children's social development is strongly influenced by the process of parental treatment or guidance to children in introducing various aspects of social life or social norms and encouraging and giving examples to children how to apply these norms in daily life. The process of parental guidance is commonly known as socialization.

Table 1.2.

Parenting Socialization and Child Behavior Development

\begin{tabular}{|l|l|}
\hline \multicolumn{1}{|c|}{ Activity for Parents } & \multicolumn{1}{|c|}{$\begin{array}{c}\text { Development of Child } \\
\text { Behavior }\end{array}$} \\
\hline $\begin{array}{l}\text { Provide nutritious food and } \\
\text { care for children's physical } \\
\text { health; }\end{array}$ & $\begin{array}{l}\text { 1. Develop trust to } \\
\text { others; }\end{array}$ \\
\hline $\begin{array}{l}\text { Train and distribute } \\
\text { physiological needs: toilet } \\
\text { training (training for } \\
\text { defecation), weaning, and } \\
\text { giving solid food; }\end{array}$ & $\begin{array}{l}\text { 2. Able to control } \\
\text { biological drives and } \\
\text { learn to channel them to } \\
\text { places that are accepted } \\
\text { by the community; }\end{array}$ \\
\hline $\begin{array}{l}\text { Teach and practice skills for } \\
\text { language, perception, } \\
\text { physical, self-care, and } \\
\text { survival ability; }\end{array}$ & $\begin{array}{l}\text { 3. Learn to recognize } \\
\text { objects of language } \\
\text { learning, walking, } \\
\text { overcoming obstacles, } \\
\text { dressing and eating; }\end{array}$ \\
\hline $\begin{array}{l}\text { Introduce environment to } \\
\text { children: family, siblings, } \\
\text { neighbors, and surrounding } \\
\text { people; }\end{array}$ & $\begin{array}{l}\text { 4. Develop an } \\
\text { understanding of social } \\
\text { behavior, and learn to } \\
\text { adjust behavior with }\end{array}$ \\
\hline
\end{tabular}

\begin{tabular}{|l|l|}
\hline & social demands; \\
\hline $\begin{array}{l}\text { Teach them about culture, } \\
\text { values (religious values), and } \\
\text { encourage children to } \\
\text { accept them as part of their } \\
\text { identity; }\end{array}$ & $\begin{array}{l}\text { 5. Develop an } \\
\text { understanding of right or } \\
\text { wrong, formulate goals } \\
\text { and criteria for choice } \\
\text { and behave well; }\end{array}$ \\
\hline $\begin{array}{l}\text { Develop interpersonal skills, } \\
\text { motive, feelings and } \\
\text { behavior in interacting with } \\
\text { others; }\end{array}$ & $\begin{array}{l}\text { 6. Learn to understand } \\
\text { other people's } \\
\text { perspectives and } \\
\text { respond selectively to } \\
\text { their opinions or } \\
\text { expectations; }\end{array}$ \\
\hline $\begin{array}{l}\text { Supervise, correct, and help } \\
\text { children to formulate } \\
\text { purpose and plan their } \\
\text { activities. }\end{array}$ & $\begin{array}{l}\text { 7. Have an } \\
\text { understanding to } \\
\text { regulate and understand } \\
\text { the criteria for assessing } \\
\text { their own appearance or } \\
\text { behavior. }\end{array}$ \\
\hline
\end{tabular}

Table 1.3

The Influence of Parenting Style towards Children's Behavior

\begin{tabular}{|c|c|c|}
\hline $\begin{array}{l}\text { Parenting } \\
\text { Styles }\end{array}$ & $\begin{array}{l}\text { Parents' Attitude or } \\
\text { Behavior }\end{array}$ & $\begin{array}{l}\text { Profile of Children's } \\
\text { Behavior }\end{array}$ \\
\hline $\begin{array}{l}\text { Authoritari } \\
\text { an }\end{array}$ & $\begin{array}{l}\text { Low "acceptance," } \\
\text { but high control; } \\
\text { Tendency to give } \\
\text { physical } \\
\text { punishment; } \\
\text { Tendency to be } \\
\text { commanding (order } \\
\text { children to do } \\
\text { something without } \\
\text { compromise); } \\
\text { Strict (harsh); } \\
\text { Tendency to } \\
\text { emotional and } \\
\text { defensive. }\end{array}$ & $\begin{array}{l}\text { Easily offended; } \\
\text { Moody, unhappy; } \\
\text { Timid; } \\
\text { Easily influenced; } \\
\text { Prone to stress; } \\
\text { Do not have clear } \\
\text { future; } \\
\text { Unfriendly. }\end{array}$ \\
\hline sive $^{\text {Permis }}$ & $\begin{array}{l}\text { High "acceptance," } \\
\text { but low control; } \\
\text { Give children } \\
\text { freedom to do what } \\
\text { they please. }\end{array}$ & $\begin{array}{l}\text { Impulsive and } \\
\text { aggressive; } \\
\text { Rebellious; } \\
\text { Lack of self- } \\
\text { esteem and self- } \\
\text { control; } \\
\text { Tend to } \\
\text { dominate; } \\
\text { Do not have clear } \\
\text { future; } \\
\text { Low achievement. }\end{array}$ \\
\hline $\begin{array}{l}\text { Author } \\
\text { itative }\end{array}$ & $\begin{array}{l}\text { High "acceptance" } \\
\text { and control; } \\
\text { Responsive towards } \\
\text { children's needs; } \\
\text { Encourage children } \\
\text { to state their } \\
\text { opinion and } \\
\text { questions; } \\
\text { Give explanation } \\
\text { about bad and/or }\end{array}$ & $\begin{array}{l}\text { Friendly; } \\
\text { Have confidence; } \\
\text { Have self-control; } \\
\text { Polite; } \\
\text { Willingness for } \\
\text { teamwork; } \\
\text { Have high } \\
\text { curiosity; } \\
\text { Have a clear } \\
\text { purpose/direction }\end{array}$ \\
\hline
\end{tabular}




\begin{tabular}{|l|l|l|}
\hline & $\begin{array}{l}\text { good consequence } \\
\text { of actions. }\end{array}$ & $\begin{array}{l}\text { of life; } \\
\text { Achievement- } \\
\text { oriented. }\end{array}$ \\
\hline
\end{tabular}

Source: Amirulloh Syarbini, Pendidikan karakter berbasis keluarga (Yogyakarta: Ar-Ruzz Media, 2016) pp. 65-66

\section{Character Building for Children at Early Age}

Why should character building be conducted from an early age? Education and psychology experts argue that the early stages of a child's life is a very important time to lay the foundations of personality that will give color when he becomes an adult. During this period, the establishment of basic sensing, thinking and growth of religious values standards is the beginning of achieving children's self-identity. Attitudes, habits and behaviors formed in the early years of a child's life determine how far the child will be able to adjust to life as an adult (Rosyadi, 2013, p. 20-21).

Ahmad Susanto $(2011$, p. 3) argues that environmental factors are very influential in the development and change of children's behavior. Therefore, in children's education, it is important to keep children away from various types of bad environment. In addition, parents should be a prime example in a child's life. Children will imitate their parents or teachers. Thus, parents must provide real examples or good examples to children because children are mirrors of their parents. Furthermore, children will imitate their surrounding environment or other media such as television, Playstation, their peers and older siblings.

Children at early age still have strong memory and their memorization is still clean; they are not yet influenced by various problems and difficulties. Children are a mandate from Allah SWT, who should be maintained and fostered. Their pure hearts are like expensive gem. They need maintenance, care, love, and attention. If their hearts are accustomed to evil and are nurtured like those of animals, they will be harmed and perish. One way to maintain pure heart is through good moral education. Therefore, parents hold the key factors to foster children with Islamic soul.

According to Rahmat Rosyadi (2013, pp. 37-38), there are some implementations of basic values of children's characteristics in a family so that children will have better attitudes, behavior, actions in living their life towards a better one. They are: (1) faith; (2) devotion; (3) honesty; (4) tolerance; (5) gratefulness; (6) diligence; (7) piety; (8) obedience; (9) loving; (10) caring; (11) discipline; (12) politeness; (13) patience; (14) affection; (15) mutual cooperation; (16) harmony; (17) togetherness; (18) tolerance; (19) nationalism; (20) empathy; (21) familiarity; (22) fairness; (23) forgiving; (24) faithfulness; (25) sacrifice; (26) responsibility; (27) safety; (28) responsiveness; steadfast; (30) healthy; (31) determination; (32) confidence; (33) elegance; proudness; (35) creative; (36) cooperation; (37) frugal; (38) thorough; (39) tenacious and (40) clean life.

6. The Role of Families in Education and Internalization of the Religious Values and National Culture

Education for children at early age must be adjusted to the level of child development. 
Child development has a certain pattern according to the development timeline. Every child has different development with other children, some are fast and some are slow. Therefore, early childhood education must be adjusted to both the scope and level of difficulty with the child's age group.

Seto Mulyadi in Anas Salahudin and Irwanto Alkrinciehie (2013, p. 286) suggested that true education is in the family, because it basically leads to individual aspects. This means that each child is valued differently and uniquely and not in a mass form. Education must be individual, from a clear heart, similar to teaching children their mother tongue, basic courtesy, respect for their parents, praying words, and prayers on time. Things like this are called educational processes. In short, families have an important role in the process of internalizing religious and moral values on their children, especially during their early age. However, moral education should not be done briskly, it should be done continuously until they grow up. It is impossible to only rely on formal education at school, because school is an institution that only focuses on education in terms of science and technology, and tends to overlook ethics and aesthetics. This kind of education can be done through education within the family. Therefore, education in the family is far more important for children's education.

\section{CONCLUSION}

Children's character building should start within the family because to shape children's micro character in a family as the smallest society unit will depend on what parents teach at early age. Children's character building in a family is not an easy task to do because it requires systemic handling. There is relation with other components such as school and its surrounding environment, which are absolutely necessary for successful character building. There are implementation of basic values of children's character within a family so that children will have better attitudes, behavior, actions in living their life towards a better one. They are (1) faith; (2) devotion; (3) honesty; (4) tolerance; (5) gratefulness; (6) diligence; (7) piety; (8) obedience; (9) loving; (10) caring; (11) discipline; (12) politeness; (13) patience; (14) affection; (15) mutual cooperation; (16) harmony; (17) togetherness; (18) tolerance; (19) nationalism; (20) empathy; (21) familiarity; (22) fairness; (23) forgiving; (24) faithfulness; (25) sacrifice; (26) responsibility; (27) safety; (28) responsiveness; (29) steadfast; (30) healthy; (31) determination; (32) confidence; (33) elegance; (34) proudness; (35) creative; (36) cooperation; (37) frugal; (38) thorough; (39) tenacious and (40) clean life.

Furthermore, character building for children at early age should begin within family using the eight family functions, including (1) Educational Function; (2) Protection Function; (3) Affection Function; (4) Socialization Function; (5) Reproduction Function; (6) Religious Function; (7) Economic Functions; and (8) Recreational Functions.

\section{REFERENCES}


Danim, S., \& Khairil. (2011). Psikologi pendidikan. Bandung: CV. Alfabeta

Deiniatur, M. (2017). Pembelajaran bahasa pada anak usia dini Melalui cerita bergambar. Jurnal Elementary 3.

El-Khuluqo, I. (2015). Manajemen PAUD. Yogyakarta: Pustaka Pelajar

Hasanah, U. (2016). Pengembangan kemampuan fisik motorik melalui permainan tradisional bagi anak usia dini. Jurnal Pendidikan Anak 5(1), p. 717.

Hasanah, U. (20xx). Pola Asuh Orangtua Dalam Membentuk Karakter Anak. Jurnal Elementary 2(1), p. 73.

Jamaluddin, D. P. (2013). Pendidikan anak dalam Islam. Bandung: CV. Pustaka Setia,

Koesoema, D. (2010). Pendidikan karakter: Strategi mendidik anak di zaman global. Jakarta: Grasindo

John, M., \& Hasan, S. (2003). Kamus InggrisIndonesia. Jakarta: Gramedia

Rachman, M. F. (2011). Islamic parenting. Jakarta: PT. Erlangga

Majid, A., \& Dian A. (2012). Pendidikan karakter perspektif Islam. Bandung: Remaja Rosdakarya

Miharso, M. (2004). Pendidikan keluarga qurani. Yogyakarta: Safira Insania Press

Moleong, J. L. (1990). Metode Penelitian Kualitatif. Bandung: Remaja Rosdakarya.

Mulyasa, E. 2012. Manajemen Pendidikan Karakter Jakarta: Bumi Aksara

Munir, A. (1993). Paradigma intelektual muslim. Yogyakarta: Sipress

Rosyadi, R. (2013). Pendidikan Islam dalam pembentukan karakter anak usia dini. Jakarta: PT. Raja Grafindo Persada
Salahudin, A., \& Irwanto, A. (2013). Pendidikan karakter: Pendidikan berbasis agama dan budaya bangsa. Bandung: CV. Pustaka Setia

Susanto, A. (2011). Perkembangan anak usia dini. Jakarta: Kencana,

Syah, M. (2010). Psikologi pendidikan dengan pendekatan baru. Bandung: Remaja Rosdakarya

Syarbini, A. (2016). Pendidikan karakter berbasis keluarga. Yogyakarta: Ar-Ruzz Media 